\title{
Psykoterapiveiledning i spesialistutdanningen
}

\author{
Psykoterapien har flere teoretiske kilder, og i de forskjellige leire vil man gjerne fremme akkurat sin teori. \\ Funn fra psykoterapiforskning tyder på at man heller burde mane til samarbeid om å integrere eksisterende \\ kunnskap.
}

Psykoterapiveiledningen i spesialistutdanningen i psykiatri har vært gjenstand for flere revisjoner. Nåværende ordning ble innført i 1969 (1) og var fra starten basert på psykoanalytisk/psykodynamisk teori, som var enerådende på den tiden. Man skulle egentlig ha veiledning $i$ to av de fem årene spesialistutdanningen varte, men dette ble først mulig i 1985, da var det blitt utdannet nok veiledere blant psykiaterne.

I desember 1993 ble Psykoterapiutvalget bedt om å evaluere ordningen og utrede hvorvidt det burde være rom for psykoterapi med annen teoretisk basis. Utvalget skulle også undersøke om det var tilgang på annen kompetanse i fagmiljøet. Som formann i utvalget førte jeg innstillingen i pennen. Den munnet ut i en rekke forslag til tiltak, bl.a. å gi rom for veiledning i psykoterapi med annen teoretisk basis (2). Det ble også foreslått å igangsette større landsomfattende utdanningsprogrammer i hhv. kognitiv atferdsterapi og interpersonlig terapi gjennom underutvalg i Psykoterapiutvalget, forutsatt tilstrekkelig interesse blant medlemmene. Flere av forslagene er senere satt ut i livet, og både gruppeterapi og kognitiv terapi kan nå godkjennes, men da i et tredje år.

Målsettingen med ordningen har alltid vært å utvikle forståelse for de basale elementene og for dynamikken i lege-pasientforholdet, for hvordan tidlige opplevelser med sentrale omsorgspersoner kunne påvirke dette samt lære mer om hvordan dette forholdet kunne gi nyttig diagnostisk informasjon og derfor er et viktig element i all psykiatrisk behandling. Denne målsettingen forklarer i stor grad hvorfor psykodynamisk teori fortsatt har en sentral plass, siden relasjonelle begreper som kontrakt, terapeutisk allianse og «forstyrrelser» i samarbeidsforholdet i form av overføring, motoverføring, motstand, utagering osv. nettopp innen denne teorien er begrepsfestet og satt inn i en større teoretisk sammenheng.

Spesialistutdanningen i psykiatri er ikke ment å skulle gi en fullstendig psykoterapikompetanse innenfor noen teoretisk retning. Det er i årenes løp mange som har ytret ønske om større plass for den teoretiske retning nettopp de står for. I Tidsskriftet nr. 20/2011 uttrykker for eksempel Kjetil Horn bekymring over at kognitiv terapi ikke er blitt tilstrekkelig vektlagt (3). Det samme kunne også vært hevdet av utøvere av andre terapiretninger, som psykoanalyse, vegeto- terapi, gruppeterapi, interpersonlig terapi, dialektisk atferdsterapi, aktiv psykoterapi, familieterapi, mentaliseringsbasert terapi, kunstterapi osv., fordi spesialistutdanningen ikke tilbyr en egen psykoterapiutdanning. For å få en mer inngående utdanning i psykoterapi må man utdanne seg ved «frittstående» institutter, hvorav de fleste er tungt subsidiert med statlige midler. Helsedirektoratet har nylig igangsatt en evaluering av aktiviteten ved de instituttene som får økonomisk støtte (Kunnskapsdepartementet ville kanskje vært mer naturlig, dersom hensikten er å se på kvaliteten av utdanningen).

\section{«Spesialistutdanningen i psykiatri er ikke ment å skulle gi en fullstendig psykoterapikompetanse innenfor noen teoretisk} retning»

\section{Ingen forskjell \\ i effekt av forskjellige terapier}

Psykoterapi har en overbevisende effekt, og gjennomsnittlig vil en som gjennomgår behandling ha det bedre enn $80 \%$ av kontrollpasientene (4). Til tross for intens forskning på effekten av forskjeller i behandlerens teoretiske bakgrunn er resultatene magre. De som har forsket på kognitiv terapi har riktignok demonstrert effekt av denne ved en del enkle symptomlidelser der annen terapi har vært brukt $\mathrm{i}$ begrenset grad. På den annen side har mange psykiatriske pasienter ofte mer komplekse problemer, og mye tyder på at psykodynamisk behandling kan ha bedre effekt hos disse (5). I store oversikter over kontrollerte og komparative studier mellom en rekke av de mest sentrale terapiformene, har man ikke lyktes i å påvise forskjeller i effekt (6). Det gjenstår imidlertid mye forskning for nøyere å kunne kartlegge hvordan spesielle pasientegenskaper kan interagere forskjellig med ulike behandlingstilnærminger.

\section{Hva er det som virker?}

Et annet viktig spørsmål er hva som virker i psykoterapi. De følgende tallene er fra en oversikt over et vidt spekter av behandlinger, diagnoser, resultatmål og varierte måter å måle pasient- og terapeutvariabler på over tid. Det viktigste funnet i denne sammenheng er at bare $15 \%$ av endringen under psykoterapi kan tilskrives teoretisk tilnærming og teknikk. Hele $30 \%$ skyldes faktorer som er felles for all psykoterapi, bl.a. empati, varme, aksept, oppmuntring til å ta sjanser, den terapeutiske alliansen og pasient- og terapeutkarakteristika. $15 \%$ skyldes placebo, dvs. pasientens tro på terapeut og metode, mens $40 \%$ skyldes faktorer utenfor terapien, slik som spontanremisjon, tilfeldige hendelser, sosial støtte fra omgivelsene osv. (4).

Sett på denne bakgrunn kan jeg ikke se at det skulle være noen grunn til å legge mer vekt på én teoretisk retning enn på andre i spesialistutdanningen. Det må være viktigere å samle den kunnskapen man har og som faggruppe insistere på at behandlingen (psykoterapi) for mange pasienter tar tid, noe det ressursmessig må tas høyde for.

\section{Hva kan man gjøre?}

Det er derfor viktig at man fremfor å bruke mer tid på enkelte terapier i langt større grad enn nå integrerer de eksisterende former for terapi ut fra forskningsfunn. De fleste av oss trenger å utvikle ydmykhet $\mathrm{i}$ forhold til våre særinteresser, noe jeg mener å se hos kolleger som har et vitenskapelig (i videste forstand) forhold til psykoterapi. På samme måte som i medisinen for øvrig er det liten kunnskap om de mekanismene som ligger bak endring, eller hvorfor og hvordan pasienter endrer seg. Vi trenger større grad av samarbeid for å prøve å forstå bakenforliggende mekanismer og for å kunne skjelne mellom intervensjoner som måtte være spesifikke for en behandling og det denne deler med andre terapier. Her har selvfølgelig utdanningsinstituttene en stor oppgave, både direkte $\mathrm{i}$ utvikling av sin terapiretning, men også indirekte fordi de utdanner veiledere til spesialistutdanningen. På begge områder tror jeg man ville tjene på å møte utfordringene i samarbeid med universitetene.

Alle som skal bli psykiatere, bør ha psykoterapiveiledning gjennom hele spesialistutdanningen. Et viktig mål må være å lære mer om egne holdninger og reaksjoner på andre. Veiledningen bør i liten 
grad vektlegge bestemte teoretiske retninger, med mindre disse representerer unike endringsmekanismer. Hovedvekt bør legges på integrasjon og på det å kunne se likheter også der hvor forskjellige begreper brukes i dag. De kliniske fenomenene går som oftest igjen, uansett hva man kaller dem.

Helst bør veiledningen utvides med nok et obligatorisk år. Innenfor dette (eller ett av de eksisterende årene) kan man la kandidatene regelmessig møtes i grupper der flere veiledere (med forskjellig bakgrunn) deltar. Målet må være å se og diskutere kliniske fenomener og dele forskjellige teoretiske synspunkter.

\section{Steinar Lorentzen}

steinar.lorentzen@medisin.uio.no

Institutt for psykiatr

Universitetet i Oslo
Steinar Lorentzen (f. 1943) er spesialist i psykiatri, professor I ved Institutt for klinisk medisin, Universitetet i Oslo, og forsker ved Avdeling for forskning og fagutvikling, Klinikk for psykisk helse og avhengighet, Oslo universitetssykehus. Han er tidligere formann i Psykoterapiutvalget i Norsk psykiatrisk forening og har lang klinisk og forskningsmessig erfaring i psykoterapi.

Ingen oppgitte interessekonflikter.

\section{Litteratur}

1. Lorentzen S, Sørlie T, Ellefsen EP, red. Psychotherapy training in the Norwegian programme for specialization in psychiatry. Nord J Psychiatry 1995: 49 (suppl 34): 5-132.

2. Innstilling om psykoterapiutdannelse i spesialistutdannelsen i psykiatri. Oslo: Psykoterapiutvalget Norsk psykiatrisk forening/Den norske lægeforening, 1995.
3. Horn K. Psykodynamisk og kognitiv terapi bør likestilles. Tidsskr Nor Legeforen 2011; 131: 1989-90.

4. Lambert MJ. Research summary on the therapeutic relationship and psychotherapy outcome. I: Norcross JC, red. Psychotherapy relationships that work). New York: Oxford University Press, 2002: 17-32

5. Leichsenring F, Rabung S. Long-term psychodynamic psychotherapy in complex mental disorders: update of a meta-analysis. British J Psychiatry 2011; 199: 15-22.

6. Lambert MJ, Ogles BM. The efficacy and effectiveness of psychotherapy. I: Lambert MJ, red. Bergin and Garfield's handbook of psychotherapy and behavior change). New York: Wiley, 2004: 139-93.

Mottatt 2.11. 2011, første revisjon innsendt 20.12. 2011, godkjent 15.1. 2012. Medisinsk redaktør Anne Kveim Lie.

\section{Farlig desinformasjon om HPV-vaksine}

Publisert først på nett 10.2. 2012

Nettutgaven til New Scientist publiserte 16.9. 2011 en artikkel skrevet av Charlotte Haug under tittelen «We need to talk about HPV vaccination - seriously» (1). Artikkelen er en oversikt over det Haug ser som ubesvarte spørsmål og potensielle faremomenter ved bruk av HPV-vaksinene.

Man skal være kritisk og man skal stille spørsmål. Problemet oppstår når man får gode svar på disse spørsmålene og man likevel fortsetter å stille de samme spørsmål som om svarene ikke finnes. Haug eksemplifiserer dette problemet der hun gjengir spørsmål og påstander som hun burde kjenne svarene til, og som flere andre har pekt ut for henne tidligere, også i Tidsskriftet, så langt tilbake som i 2008 (2).

Et par eksempler: Haug påpeker som korrekt er, at dagens godkjente vaksiner bare beskytter mot to varianter av høyrisiko HPV, type 16 og 18. Ettersom disse bare er to av rundt $15 \mathrm{kreftfremkallende} \mathrm{varianter,}$ synes Haug å mene at vaksinen har lite for seg. Det hun ikke skriver, men inderlig godt vet, er at disse to variantene er årsak til minst $70 \%$ av alle tilfeller av livmorhalskreft (3). Kombinert med den kryssbeskyttelse mot andre varianter som hun selv nevner, er det mulig at beskyttelsen i praksis er enda høyere. Det er vanskelig å se at dette ikke er en beskyttelse av stor verdi. I tillegg er det slik at hele $92 \%$ av tilfellene av livmorhalskreft hos kvinner under 35 år skyldes HPV 16 og 18 (4), noe som gjør vaksinen enda viktigere.

Haug fortsetter med å peke på bivirkningene som er innrapportert gjennom VAERS, og nevner bl.a. 32 dødsfall blant 23 millioner vaksinerte jenter i USA i perioden juni 2006 til desember 2008. Hun ramser også opp andre alvorlige bivirkninger, og påpeker at det ble rapportert inn hele 12424 bivirkninger i nevnte periode. Det hun ikke sier, er at $94 \%$ av disse ikke ble regnet som alvorlige (hodepine, kvalme, svimmelhet etc.), og ikke opptrådte hyppigere enn med andre vaksiner eller i placebogruppen (5). Det er ikke registrert høyere antall av de alvorlige bivirkningene enn hos den øvrige befolkning. Det er ikke sett noen sammenheng mellom disse 32 dødsfallene og vaksinen. Flere av dem er dokumentert å ha andre årsaker. Erfaring fra Norge viser også at bivirkningene er som forventet, og at de ikke er av alvorlig art (6).

Det problematiske med Haugs artikkel er ikke så mye at hun er kritisk til vaksinen. Problemet er at innvendingene hennes mot vaksinen ikke er fundamentert i god vitenskap og rådende kunnskap. Charlotte Haug burde vite bedre, men velger å lukke øynene. Det er alvorlig og farlig.

\section{Gunnar Tjomlid}

gunnar@tjomlid.com

Oslo
Gunnar R Tjomlid (f. 1974) er daglig leder og webutvikler i IT-selskapet Thin as. Han er styremedlem i Foreningen Skepsis, aktiv blogger på blog.tjomlid.com, medvirkende i podkasten Saltklypa (saltklypa.no), og freelanceskribent for bl.a. FriTanke.no.

Ingen oppgitte interessekonflikter.

\section{Litteratur}

1. Haug C. We need to talk about HPV vaccination seriously. New Scientist 16.9.2011. www. newscientist.com/article/dn20928-we-need-totalk-about-hpv-vaccination--seriously.html (1.11.2011).

2. Flaten 0 , Thoresen S. Feil fra redaktøren om HPVvaksine. Tidsskr Nor Legeforen 2008; 128: 1424

3. Muñoz N, Bosch FX, Castellsagué X et al. Against which human papillomavirus types shall we vaccinate and screen? The international perspective. Int J Cancer 2004; 111: 278-85.

4. Carozzi FM, Tornesello ML, Burroni E et al. Prevalence of human papillomavirus types in high-grade cervical intraepithelial neoplasia and cancer in Italy. Cancer Epidemiol Biomarkers Prev 2010; 19 2389-400.

5. Centers for Disease Control and Prevention. Summary of HPV Adverse Event Reports Published in JAMA www.cdc.gov/vaccinesafety/Vaccines/HPV/ jama.html (1.11.2011).

6. Statens legemiddelverk. Bivirkninger av HPV-vak sine (Gardasil). www.legemiddelverket.no/ templates/InterPage__83189.aspx (1.11.2011). 